\title{
THE RELATIONSHIP BETWEEN DISCHARGE PLANNING AND THE QUALITY OF LIFE OF PATIENTS WITH DIABETIC ULCER
}

\author{
Candra Kusuma Negara ${ }^{1 *}$, Abd. Basid ${ }^{2}$, Sri Erliani ${ }^{3}$, Inaya Turahman ${ }^{4}$ \\ 1,2,3,4 Institute of Health Science Cahaya Bangsa Banjarmasin \\ Email*: candra14780@yahoo.com
}

\begin{abstract}
Introduction: Diabetic ulcer is one of the chronic complications of diabetes mellitus. Several studies in Indonesia reported that the mortality rate of gangrene ulcers in people with diabetes ranged from 17-32\%, and diabetic ulcers affected the quality of life of sufferers. All patients hospitalized require discharge planning. From the explanation above, it can be concluded that Diabetes Mellitus is a degenerative disease that indeed requires hospitalization. The purpose of this study is to find out whether the Discharge planning process has a relationship with the quality of life of patients with Diabetic Ulcers. Methods: With the Ex post facto study design, 28 respondentwho were in accordance obtained measurements of discharge planning processes using interview methods and measurements on quality of life using the WHOQOL-BREEF questionnaire with spearman rank non parametric correlation analysis methods. Results: The results of the value are obtained: $\alpha=0.05$ with = rs table (0.707), RHO count (0.949)>rs table then categorized in the table Relationship Strengths correlation results obtained in this category is very strong / near perfect with the value 0.76-1.00. Conclusions:This shows that there is a significant relationship with the strength of a very strong / near-perfect relationship according to the table.
\end{abstract}

Keywords: diabetes; discharge planning; quality; ulcer

\section{INTRODUCTION}

Diabetic ulcer is one of the chronic complications of diabetes mellitus. The presence of open sores on the skin layer into the dermis that occurs due to blockages in the blood vessels in the legs and peripheral neuropathy due to high blood sugar levels so that patients are not aware of any wounds (Waspadji, 2006).

Nearly $14 \%-24 \%$ of patients with diabetic ulcers require amputation, which means that every 30 seconds a person's lower limb is lost due to diabetes. The Global Lower Extremity Change Study Group estimates that 25\% -90\% of all amputations are associated with diabetes. The American Diabetes Association estimates that amputation of the ulcer legs will continue to increase. $15 \%$ of people with DM will experience ulcers during their lifetime, and $24 \%$ of people with foot ulcers will need amputations (Funnel, Brown, Childs, \& Haas, 2011).

If amputation is the management choice for diabetic foot, not only is the aesthetic lost, but self-confidence can also be lost as a consequence of the amputation (Norris, 2002). Quality of life is a conceptual or operational measure that is often used in situations of chronic illness as a way to assess the impact of therapy on patients (Asmadi, 2008).

Diabetic as a complication of DM requires more comprehensive care. The healing rate of ulcer patients is not only from the hospital but also from the patient himself and his family, especially how to know discharge planning such as how to administer follow-up care at home to DM patients to speed up the healing process and reduce complications to a level more serious.

Planning to return the ulcer patient is different from the other cases because it requires comprehensive action and involves the closest family members in the maximum recovery process. This study generally aims to determine the relationship of Discharge Planning to the quality of life of patients with Diabetic Ulcers at RSUD H. Moch. Ansari Saleh Banjarmasin, South Kalimantan

\section{METHODS}

The variables used in this study are Discharge Planning (Independent) and Quality Of Life (dependent). This research uses ex post facto method with Cross Sectional approach, population of 54 people with a sample of 28 
The Relationship Between Discharge Planning ... (Candra Kusuma, et.al)

Table 1. Distribution of Respondent According to Demographic

\begin{tabular}{|c|c|c|}
\hline Characteristics & Frequency (n) & Percentage (\%) \\
\hline \multicolumn{3}{|l|}{ Gender } \\
\hline 1. Male & 13 & 46.4 \\
\hline 2. Female & 15 & 53.6 \\
\hline Total & 28 & 100 \\
\hline \multicolumn{3}{|l|}{ Age } \\
\hline 1. $30-40$ years & 9 & 32.1 \\
\hline 2. 41-50 years & 11 & 39.3 \\
\hline 3. >51 years & 8 & 28.6 \\
\hline Total & 28 & 100 \\
\hline \multicolumn{3}{|l|}{ Level of Education } \\
\hline 1. Primary School & 2 & 7.1 \\
\hline 2. Junior High School & 9 & 31.1 \\
\hline 3. Senior High School & 15 & 51.6 \\
\hline 4. Bachelor & 3 & 10.1 \\
\hline Total & 28 & 100 \\
\hline \multicolumn{3}{|l|}{ Work } \\
\hline 1. House Wife & 10 & 35.1 \\
\hline 2. Private & 15 & 53.2 \\
\hline 3. Government Employees & 3 & 11.7 \\
\hline Total & 28 & 100 \\
\hline
\end{tabular}

Table 2. Bivariate analysis

\begin{tabular}{|c|c|c|c|c|c|c|}
\hline \multirow{2}{*}{$\begin{array}{c}\text { Discharge } \\
\text { planing }\end{array}$} & \multicolumn{4}{|c|}{ Quality Of Life } & \multirow{2}{*}{ Total } & \multirow{2}{*}{$\%$} \\
\hline & \multicolumn{2}{|r|}{ Good } & \multicolumn{2}{|c|}{ Bad } & & \\
\hline & $\mathbf{F}$ & $\%$ & $\mathbf{F}$ & $\%$ & & \\
\hline Good & 16 & 80 & 5 & 25 & 21 & 75 \\
\hline Bad & 4 & 20 & 3 & 15 & 7 & 25 \\
\hline \multirow[t]{2}{*}{ Total } & 20 & 71 & 8 & 29 & 28 & 100 \\
\hline & \multicolumn{4}{|c|}{ R-tabel $=0.643$} & Rho & 949 \\
\hline
\end{tabular}

people, analysis of data using sperman rank. With the Ex post facto study design, obtained measurements of discharge planning processes using interview methods and measurements on quality of life using the WHOQOL-BREEF questionnaire with spearman rank non parametric correlation analysis methods. WHOQOL-
BREEF is a questionnaire used for health surveys to assess the dependent variable namely quality of life, which consists of 5 functional scales with 26 questions. Quality of life score between 0-100 is approved with good quality of life score 51-100 and approved poor quality of life score 0-50 after calculating the average value of 4 health 
dimensions, the questionnaire in this study was adopted from the questionnaire used by (Yusra, 2011).

Inclusion criteria:All patients suffering from Diabetes with Diabetic Ulcer in the internal medicine room, and Willing to be a respondent communicate well.Exclusion criteria: Diabetespatients not with Diabetic Ulcers, and Patients who have health problems other than Diabetes.

Based on the research ethical feasibility statement No. 352 / II-Reg Research / RSUDU / 19 from the Research Ethics Commission of Ulin Hospital Banjarmasin, this research is ethical.This study has been conducted in hold principle of research ethics like anonymity, autonomy, veracity, beneficence, justice and informed consent also.

\section{RESULTS}

From the table 1, it can be concluded that the characteristics of the respondents with the most sex are 15 people (53.6\%), the age of the respondents with the highest age range 41-50 years as many as 11 people (39.3), the highest level of education is as high as 15 people (51.6\%), and most jobs are private as many as $15(53.2 \%)$.

From the results of the table 2, it was found that the quality of life of patients with good Discharge Planningwas 16 respondents (80\%), good quality of life with poor Discharge Planningas many as 4 respondents (20\%), poor quality of life with good Discharge Planningas many as 5 respondents (25\%), and poor quality of life with poor Discharge Planningas many as 3 respondents (29\%).

The statistical test results about the relationship between release planning and quality of life in Dr.Moch.Anshari Saleh Hospital, with the Rank Spearmen test obtained results $h_{\chi \gamma}=$ $0.949>$ from $\mathrm{R}$ table (0.707) The result is $\mathrm{Ha}$ Accepted, and cultural results to determine inner strength Obtained from the results of $h_{\chi \gamma}=0.949$ the relationship with sperman entered in the category of very strong / perfect between the independent variables, namely planning discharge to the dependent variable, namely the quality of life in Dr.Moch.Anshari Saleh Hospital Banjarmasin.
The question of Discharge Planningfor good and bad categories consists of 6 positive questions and 6 negative questions totaling 12 questions: 1.Is there receiving or getting health information,2. Health information about the disease suffered, 3.Health education from nurses regarding Diabetes with Diabetic Ulcers, 4.Other health information, 5. Information about the treatment given, 6. Information about follow-up care at home.

\section{DISCUSSIONS}

The results showed that most of the 28 people with Discharge Planning who had good quality of life were 20 people $(71 \%)$ and 8 people (29\%) who had poor quality of life. It was found that out of 28 people who had good quality of life with discharge planning 16 people $(80 \%)$ and 5 people $(25 \%)$ had poor discharges. The results of this study are in line with the results of the research conducted by (Negara, 2018) the same examine the relationship of discharge planning to quality of life but have differences in the characteristics of the dependent variable, the results of the study show there is a relationship between Structured Discharge Planning on Quality of Life in ischemic stroke patients.

The results showed that most respondents had a good quality of life of 16 people $(80 \%)$ and poor quality of life as many as 5 people $(25 \%)$. This was stated by Testa and Nackley, that quality of life means a range between objective and subjective perceptions of them(Rapley, 2003). Nackley describe quality of life as a set of physical, functional, psychological, and health related parts. social from individuals. When used in this context, it often leads to quality of life that leads to health.

The quality of life of patients with diabetes mellitus is influenced by various factors both medically and psychologically. These factors include understanding of diabetes, adjustments to diabetes, depression, self regulation (Watkins et all, 2000) with hospitalization in the form of discharge planning which is applied to diabetes mellitus patients with ulcers. see from the frequency distribution table above the age most suffer from diabetes is the age of 41-50 years as many as 11 respondents (39.3\%) according to Andayani(2005) one of the 
risk factors for DM is age. Generally humans experience physiological changes that decline rapidly after the age of 40 years.

Further analysis shows of the number of female gender patients is more than 15 respondents $(53.6 \%)$. this is in line with some of the results of the research of Chaveeponjkamjorn et al (2008) regarding the quality of life and adherence of DM patients to the majority $(76.7 \%)$ of whom were women. Likewise, the study of Gautam et al (2009) on the cross-sectional study of the quality of life of DM patients in India, most $(65 \%)$ were female.

The next analysis is the relationship between the level of education and the quality of life. the highest level of education of respondents is high school as much as $15(51.6 \%)$. in line with the study conducted by Hensarling (2009), that $70 \%$ of type $2 \mathrm{DM}$ respondents in their study were in the category of higher education. so also Awadalla (2006), in his research on family support for DM patients, found that most respondents were highly educated $(80 \%)$. In contrast to Mierer al (2008) in a cross-sectional study of DM patients, found that most respondents had low education $(70 \%)$. so is the research of Wen et al (2004), where DM respondents who have lower education are more than higher education. in line with Goz et al (2006), in research at the Turkish hospital polyclinic, where most of the respondents were low educated.

Of the total respondents who were studied at the RSUD dr. H. MOCH. ANSARI SALEH Banjarmasin in 2018 is more dominant to have a good quality of life, and the phenomenon found is not in line with the opinions of experts who state that Diabetes with Diabetic Ulcer wounds is an aspect that affects quality of life because the number of respondents who are dominantly researched has a good quality of life category assessed using a questionnaire measurement tool used for measuring quality of life with questions that have dimensions of health measurement namely, physical, functional, psychological, and social health. The quality of life in this study is related to the discharge planning process provided that the patient is hospitalized with the meaning of Discharge Planning that has a major influence on improving the quality of life of diabetic ulcer patients and can be used as a reference for future research.

The results of this study indicate that respondents Discharge Planning who have a dominant good category have a good Quality of Life status, meaning Discharge Planning is one that can affect the quality of life and has a significant relationship. And there are several other factors that can influence and have a dominant role that can affect quality of life such as age, gender, type of work, duration of hypertension, marital status, education, regular treatment and, blood pressure, social relations (Karangora, 2012).

All patients hospitalized require a Discharge Planning Association (Lisser, 2005). Patients and all family members must get information about all repatriation plans. The Royal Marsden Hospital (2004) in (Fiman, Endah, \& Dadang, 2012) states that discharge planning is a process of identifying patient needs and plans written to facilitate sustainability a health service from one environment to another. From the explanation above regarding Diabetes Mellitus which is a degenerative disease that does require hospitalization, it is necessary to have a Discharge Planning Program for advanced health services.

The dominant factors that affect quality of life are such as marital status, education level, economic status, family support, and regularity of treatment which causes the quality of life to be optimal or vice versa. Because the quality of life is a range between the objective and subjective perceptions of the individual.

\section{CONCLUSIONS}

The Conclusion can be concluded that in this study there was a significant relationship between Discharge Planning on the quality of life of patients with Diabetic Ulcers with the categories of relationships that were determined using the culton table which is included in the category of relations of strong / near perfect correlation with a value of $0.76-1.00$ available in Dr.Moch.Anshari Saleh Hospital.

\section{REFERENCES}


Aini Yusra. (2011). Hubungan Antara Dukungan Keluarga Dengan Kualitas Hidup Pasien DM Tipe 2 Di Poliklinik Penyakit Dalam Rumah Sakit Umum Pusat Fatmawati Jakarta. Tesis. Universitas Indonesia. Jakarta.

Andayani, T.M. (2010). The Association of diabetes-related factor and quality of life Diabetes

mellitus. International Journal of Pharmacy and Pharmaceutical Sciences, 2 (1), 139-

145.

Asmadi. (2008). Konsep Dasar Keperawatan. Jakarta: EGC.

Awadalla,A.W., Ohaeri, J.U., AL-Awadi, S.A., \&Tawiq, A.M. (2006). Diabetes Mellitus Pattients family caregivers subjective quality of life. Journal Of National Medical Association, 98 (5), 727-736.

Chaveepojnkamjorn, W., Pichainarong, N., Schelp, F.P., \&Mahaweerawat, M.U. (2008). Quality of life and compliance among type 2 diabetic patient, Southest Asian Journal Trop Med, Public Health, 39 (2), 328-334

Fiman, Endah, \& Dadang. (2012). Kualitas Hidup Pasien Ulkus Diabetik Di Rymah Sakit Umum Daerah Serang. Banten.

Funnel, M. M., Brown, T. L., Childs, B. P., \& Haas, L. B. (2011). National Standards For Diabetes Self-Management Education. Diabetes Care, https://www.ncbi.nlm.nih.gov/pmc/articl es/PMC3006053/.

Gautam, Y., Sharma, A.K., Agrarwal, A.K., Bhatnagar, M.K., \&Trehan, R.R. (2009). Effect of the diabetic patiens's perceived social support on their quality of life. Journal Of Clinic Nursing, 16, 13531360.

Goz, F., Karoz., S., Goz, M., Ekiz, S., \& Cetin, I. (2007). Effect of the diabetic patient's perceived social support on their quality of life. Journal Of Clinical Nursing, 16, 1353-1360.
Hensarling, J. (2009). Development and psychometric testing of Henserling's diabetes family support scale, a dissertation Degree of Doctor of Philosophy in the Texa's Women's University.

Karangora, M.L.B. (2012).

HubunganantaraDukunganSosialdanKu alitasHiduppada Lesbian di Surabaya.

JurnalIlmiahMahasiswaUniversitas Surabaya, Vol. 8, No. 1.

Lisser, T. D. (2005). Discharge Planning Association. USA: DPA.

Mier,N., Alonso, A.B., Zhan, D., Zuniaga, M.A., \& Acosta, R.I. (2008). Health-related quality of life in a binational population with diabetes at the Texas- Mexico border. Rev PanamSaludPublica, 23 (3), 154-163

Negara, C. K. The Effect of Discharge Planning on Treatment Adherence among The Elderly with Hypertension in Banjarmasin, South

Kalimantan. In 4th International Conference on Public Health 2018 (pp. 237-237).

SebelasMaret University.

Norris.S.L. (2002). Increasing Diabetes SelfManagement Education In Community Setting: A Systematic Review. American Journal Of Preventive Medicine, 3(9), 39-53.

Rapley, Mark. (2003). Quality of Life Research A Critical Introduction. London: SAGE Publications, Inc.

Watkins KW' Connell CM, Fitzgerald JT, Klem L, Hickey T, Ingersoll-Dayton B. (2000). Effect Of Adults Self Regulation Of Diabetes On Quality Of Life Outcomes. Journal Center For Biotechnology Information, 23(10), 1511-5

Waspadji, S. (2006). Buku Ajar Ilmu Penyakit Dalam (IV ed., Vol. 3). Universitas Indonesia.Jakarta.

Wen L.K. (2004). Familly support and diet barriers among older Hispanic adults with type 2 diabetes. Clinical Research and Methods. 36 (6), 423-430. 